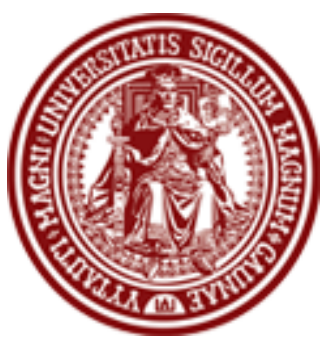

DE DE GRUYTER OPEN

\section{BALTIC JOURNAL OF LAW \& POLITICS}

A Journal of Vytautas Magnus University

VOLUME 10, NUMBER 1 (2017)

ISSN 2029-0454

\title{
THE ROLE OF JUDICIAL ETHICS IN COURT ADMINISTRATION: FROM SETTING THE OBJECTIVES TO PRACTICAL IMPLEMENTATION
}

\author{
Mindaugas Šimonis \\ Ph.D. Student; Judge and Chairman of Civil Cases Division \\ Vytautas Magnus University, Faculty of Law (Lithuania) \\ Kaunas Regional Court (Lithuania) \\ Contact information \\ Address: Jonavos str. 66, LT-44191 Kaunas, Lithuania \\ Phone: +37037751044 \\ E-mail address: mindaugas.simonis@vdu.It
}

Received: January 5, 2017; reviews: 2; accepted: June 16, 2017.

\begin{abstract}
A court administration striving to guarantee the independence and professionalism of the court and judges requires attention to judicial ethics. Judicial ethics as a system of professional values and as an institutional instrument of judiciary is an integral part of court administration which is based on the principle of self-regulation. The importance of court administration requires a scientific approach to its elements. Therefore, this article begins by providing analysis of the main objectives of judicial ethics and a comparative study on the European practices establishing judicial ethics. It also provides a systematic list of the basic principles of the conduct of judges that are established in different international standards and legal systems of different European countries. By analysing documents of different international institutions and codes of ethics of European countries, the author identifies a systematic structure and the fundamental starting point of modern judicial ethics. The
\end{abstract}


methods of descriptive comparative analysis and observation of recent developments are dominant in this study. Reacting to the scientific problems and current needs of legal communities with regard to the enforcement of judicial ethics, the article presents approaches that could lead to increased effectiveness of ethics in the judiciary, as well as to the development of methods of enforcement of judicial ethics. The purpose of this article is not just to disclose the main international standards and regulations on judicial ethics in Europe, but also to make it practically valuable for developers of judicial ethics, taking into consideration the fact that recently many countries have been trying to reform and improve ethical systems in the judiciary. Given the limited scope of this article, other important elements of court administration and developing a comparative study of the content of judicial ethics and the jurisprudence of its implementation will be presented in future publications.

\section{KEYWORDS}

Judicial ethics, objectives of judicial ethics, establishment of judicial ethics, basic principles of the conduct of judges, enforcement of judicial ethics 


\section{INTRODUCTION}

Judicial ethics is the professional ${ }^{1}$ applied $^{2}$ ethics of judges having crucial importance in the administration of justice and gaining more and more attention as a domain of comparative and interdisciplinary (especially having in mind the fields of law, politics and administration) scholarly research. The Consultative Council of European Judges (CCJE) in Opinion no. 3 emphasized that the ethical aspects of judges' conduct need to be discussed for various reasons. The methods used in the settlement of disputes should always inspire confidence. The powers entrusted to judges are strictly linked to the values of justice, truth and freedom. The standards of conduct applying to judges are the corollary of these values and a precondition for confidence in the administration of justice. ${ }^{3}$

Scientific dilemmas related to judicial ethics are determined by the fact that it is considered to be governmental ethics and the ethics of the third state power. Ethical judicial dilemmas arise very often because of the concurrence of special power and service, namely, that both are an integral part of the judiciary. The complexity of judicial ethics is determined by judges' specific constitutional status, their immunity and need of protection, as well as by the wide scope of values, its sensitivity and diversity. The European Network of Councils for the Judiciary has noted that society's expectations for judges have caused the need to reflect on the question of judicial ethics. In European societies, the judge's role has evolved: it is no longer confined to being "the mouthpiece of the law"; the judge is also, to a certain extent, a creator of law, which requires responsibilities and ethical rules consistent with this evolution.

These global developments of judicial practice confirm the need for comparative scientific research, especially taking into consideration different European cultures, legal procedural traditions and historical heritage that determine various approaches to judicial ethics. Continuing globalization processes along with

\footnotetext{
1 The term professional ethics designates one or more of the following: 1) the justified moral values that should govern the work of professionals; 2) the moral values that actually do guide groups of professionals, whether those values are identified as (a) principles in codes of ethics promulgated by professional societies or (b) actual beliefs and conduct of professionals; and (3) the study of professional ethics in the preceding senses, either (i) normative (philosophical) inquiries into the values desirable for professionals to embrace, or (ii) descriptive (scientific) studies of the actual beliefs and conduct of groups of professionals (The Cambridge Dictionary of Philosophy, $2^{\text {nd }}$ edition (Cambridge University Press 1995, 1999), 749 // http://stoa.usp.br/rdeangelo/files/-1/10954/Cambridge+Dictionary+of+Philosophy.pdf).

2 Applied ethics is the domain of ethics that includes professional ethics, such as business ethics, engineering ethics, and medical ethics, as well as practical ethics, such as environmental ethics, which is applied, are thus practical as opposed to theoretical but not focused on one discipline (ibid., 34).

3 Opinion no. 3 of the Consultative Council of European Judges (CCJE) to the attention of the Committee of Ministers of the Council of Europe on the principles and rules governing judges' professional conduct, in particular ethics, incompatible behaviour and impartiality, Strasbourg (November 19, 2002) // https://wcd.coe.int/ViewDoc.jsp?p=\&id=1046405\&Site=COE\&direct=true.
} 
the unification of legal systems and judicial procedures requires identifying common values of judicial ethics in European countries and around the world; therefore, a comparative study of contemporary best practices is highly relevant. It becomes even more relevant taking into account the rise of a global justice which is very often related with the proliferation of international courts and tribunals. ${ }^{4}$ When the question of how global standards for a good performance of the judiciary is achieved, judicial ethics and judicial codes of conduct may be posed as the best answer to this question. ${ }^{5}$

Norms of judicial ethics can be found both in national legal systems and in the documents of different international organizations. It is established by soft law as well as by binding law. Judicial ethics is the highest constitutional ethics because the main principles of judicial conduct (independence, impartiality, integrity, equality, etc.) are legal principles established in the constitutions of different European countries. In the countries with the status of a state under the rule of law, it is especially significant because the essential values of judicial ethics are prerequisite of this constitutional principle.

In many European countries expectations for professional and sensitive justice in the society have always been an issue of great importance. But it became even more important during the time of social and economic deficiencies which increased the amount of social conflict. Consequently, courts face the mission not just to solve a huge number of disputes, but also to decide on very sensitive social issues, which require not just legal professionalism, good knowledge of international jurisprudence on human rights issues, but also over-arching work in different areas that is regulated by law. Proper conduct in compliance with judicial ethics helps judges to overcome these challenges successfully. Therefore, the aim of this analysis on judicial ethics and the expected final outcome is focused on disclosing the current situation and, as a comparative study, on finding common principles which could help for future developments and the practical implementation of ethics in the judiciary.

The starting point of getting deep into any social field requires revealing its nature. This is even more important for judicial ethics because misunderstanding its nature can lead to serious confusion and antagonistic results, or even worse, a violation of judicial independence. Scientific research into judicial ethics is of high necessity and is still very novel because this area of ethics is continuously

\footnotetext{
${ }^{4}$ Jörg Philipp Terhechte, "Judicial Ethics for a Global Judiciary - How Judicial Networks create their own codes of conduct," German Law Journal 10 (2009): 504 // http://www.leuphana.de/fileadmin/user_upload/PERSONALPAGES/_st/terhechte_joergphilipp/files/Judicial_Ethics_for_a_Global_Judiciary_-_How_Judicial_Networks_Create_their_own_PDF_Vol_10_No_04_501-514_SI_Articles_Terhechte.pdf.

5 Ibid.: $5 \overline{14}$.
} 
developing and has complex objectives. Therefore, the author decides to start analysis of this topic by providing an overview of the objectives of judicial ethics.

\section{THEORETICAL BACKGROUND: OBJECTIVES OF JUDICIAL ETHICS}

Judicial ethics can generally be recognized as ensuring the independence, impartiality and integrity (the three big "I") of courts and judges, which have always been recognized as the core values in a democratic society, as reasonably expected from the judiciary. Justice is a fundamental precondition for developments in any of its fields: state governance, politics, economic, science, welfare, etc. The specific nature of administering justice, its sensitivity and complexity, must be taken into consideration. For people, the rule of procedural justice is not less important than material justice, because justice could be perceived as a form of human consciousness. The European Court of Human Rights has highlighted that justice must not only be done, it must also be seen to be done. ${ }^{6}$ It should be noted that the persuasive and trustworthy practice of judges is of immense importance for the final effectiveness in administration of justice. Therefore, judicial ethics which establishes and ensures the principles of professional conduct of judges should raise specific objectives in various parts of judges' activities. The Consultative Council of European Judges has declared that "the confidence in the justice system is even more important in view of the increasing globalization of disputes and the wide circulation of judgments. Furthermore, in a State governed by the rule of law, the public is entitled to expect the general principles, compatible with the notion of a fair trial and guaranteeing fundamental rights, to be set out. The obligations incumbent on judges have been put in place in order to guarantee their impartiality and the effectiveness of their action." 7 Developing ethics regimes and standards for justice is recognized as one of the measures to combat corruption by implementing article 11 of the United Nations Convention against Corruption and increasing the effectiveness of courts and reducing both the incentives and opportunities for judicial corruption. ${ }^{8}$

The main source of modern judicial ethics in the world is undoubtedly the Bangalore Principles of Judicial Conduct ${ }^{9}$. These principles were adopted by the

\footnotetext{
6 Delcourt v. Belgium, European Court of Human Rights (ECHR) (January 17, 1970).

7 Opinion no. 3 of the Consultative Council of European Judges (CCJE), supra note 3.

8 Jessica Schultz, "The UNCAC and judicial corruption: Requirements and avenues for reform", AntiCorruption Resource Centre (2009)//

http://www.u4.no/publications/the-uncac-and-judicial-corruption-requirements-and-avenues-forreform/.

9 Adopted by the round table meeting of Chief Justices, held in The Hague on 25 and 26 November 2002, which was attended by senior judges of the civil law tradition as well as judges of the International Court of Justice. See Bangalore Principles of Judicial Conduct (2002) // http://www.unodc.org/pdf/crime/corruption/judicial_group/Bangalore_principles.pdf.
} 
Judicial Group on Strengthening Judicial Integrity, and revised at the Round Table Meeting of Chief Justices held at the Peace Palace, The Hague, November 25-26, 2002. The process of establishing the Bangalore Principles of Judicial Conduct is described in the Commentary on the Bangalore Principles of Judicial Conduct issued by the United Nations Office on Drugs and Crime in 2007. ${ }^{10}$ At the first meeting of the Judicial Group on Strengthening Judicial Integrity the participating judges emphasized that by adopting and enforcing appropriate standards of judicial conduct among its members the judiciary would have the power to take a significant step towards earning and retaining the respect of the community. ${ }^{11}$ The intentions in adopting the Bangalore Principles of Judicial Conduct were not only to establish standards for ethical conduct of judges but also to provide guidance to judges and to provide the judiciary with a framework for regulating judicial conduct. They are also aimed at assisting members of the executive and the legislature branches, as well as lawyers and the public in general, to better understand and support the judiciary. These principles presuppose that judges are accountable for their conduct to appropriate institutions established to maintain judicial standards, which are themselves independent and impartial, and are intended to supplement and not to derogate from existing rules of law and conduct that bind the judge. ${ }^{12}$ As Greg Mayne has noted correctly the Bangalore Principles are primarily directed at judiciaries for implementation and enforcement, rather than the state. He also emphasized that the chief weakness of the Bangalore Principles lies in their enforcement, because they are not contained in a binding document under International law and it appears to offer guidance to members of the judiciary, rather than to set out directly enforceable standards of behaviour, and therefore may not have a direct impact on improving judicial conduct. ${ }^{13}$ Nevertheless, the new establishments and reformations in the judiciaries confirm that most of the countries in Europe and in other states in the world recognize the Bangalore Principles as the most authoritative and modern approach to the judicial ethics.

One of the last approaches made in June 2015 by the International Association of Judicial Independence and World Peace is the Bologna Milano Global Code of Judicial ethics, approved at the International Conference of Judicial independence held at the University of Bologna and at Bocconni University of

\footnotetext{
10 Adopted by the judicial integrity group of United Nations Office on Drugs and Crime. Open-ended intergovernmental expert group meeting on strengthening basic principles of judicial conduct, held on 1 and 2 March 2007 at the United Nations Office at Vienna. See Commentary on the Bangalore Principles of Judicial Conduct (September 2007) //

https://www.unodc.org/documents/corruption/publications_unodc_commentary-e.pdf.

11 Ibid.: 10.

12 Ibid.: 36.

13 Greg Mayne, "Judicial integrity: the accountability gap and the Bangalore Principles," Global Corruption Report (2007) //

http://unpan1.un.org/intradoc/groups/public/documents/un-dpadm/unpan045153.pdf.
} 
Milano. ${ }^{14}$ As it is stated in the preamble, the Global Code of Judicial ethics is intended to clarify standards for ethical conduct of judges. The Code is designed to provide guidance to judges and to afford the judiciary a framework for regulating judicial conduct.

The European Network of Councils for the Judiciary ${ }^{15}$ in the Report 2009-2010 on Judicial ethics ${ }^{16}$ stated that the affirmation of principles of professional conduct for judges strengthens public confidence and allows better understanding of the role of the judge in the society. The network emphasized that judicial ethics has been addressed in a positive manner, so that the duties of a judge encompass the common founding values of a judge's work, preventive principles and personal qualities, in response to the public's expectations. It is essential that judges, individually and collectively, respect and honour the judicial office as a public trust and strive to enhance and maintain confidence in the judicial system. ${ }^{17}$

The European Court of Human Rights, by adopting a Resolution on Judicial Ethics in $2008,{ }^{18}$ announced that the intention is to bring more transparency to the obligations inherent in judicial office, thereby enhancing public confidence in the court. It is appropriate, in the interests of clarity and transparency, to articulate the principles of Article 21 of European Convention on Human Rights, which sets forth the criteria for judicial office. In the Code of Judicial Ethics of the International Criminal Court, it is stated that the principles embodied in this code shall serve as guidelines on the essential ethical standards required of judges in the performance of their duties. They are advisory in nature and have the object of assisting judges with respect to ethical and professional issues with which they are confronted. It is also emphasized that nothing in this code is intended in any way to limit or restrict the judicial independence of judges. ${ }^{19}$

Objectives of judicial ethics in different European countries disclose different aims than the judiciary is expecting by codifying norms of ethics. The culture of the judiciary is examined by taking into consideration the essential goals and political views of the countries' judiciaries. In this article, comparative study of

\footnotetext{
14 Bologna and Milan Global Code of Judicial Ethics (2015) // http://www.jiwp.org/\#!global-code-ofjudicial-ethics/c1dnr.

${ }^{15}$ European Network of Councils for the Judiciary unites the national institutions in the Member States of the European Union which are independent of the executive and legislature, and which are responsible for the support of the Judiciaries in the independent delivery of justice. Networks aim is to improve cooperation between, and good mutual understanding amongst, the Councils for the Judiciary and the members of the Judiciary of the European Union (or candidate) Member States.

${ }_{16}$ Judicial Ethics Report 2009-2010, ENCJ Working Group //

http://www.encj.eu/images/stories/pdf/ethics/judicialethicsdeontologiefinal.pdf.

17 Ibid.: 9.

18 Resolution on Judicial ethics adopted by the European Court of Human Rights (Plenary Court) (June 23, 2008) // http://www.echr.coe.int/Documents/Resolution_Judicial_Ethics_ENG.pdf.

${ }_{19}$ The Code has been adopted by the judges of International Criminal Court. See Code of Judicial Ethics of International Criminal Court, ICC-BD/02-01-05 // https://www.icc-cpi.int/NR/rdonlyres/A62EBC0FD534-438F-A128-D3AC4CFDD644/140141/ICCBD020105_En.pdf.
} 
objectives of judicial ethics in different European countries helps to identify the recent dilemmas that judiciaries face nowadays.

The Code of Judicial Ethics in Croatia of 2006 stresses that the code is established in order to achieve the highest values of the constitutional order of the Republic of Croatia, the rule of law, constitutionality and legality, humanity and ethics as well as the protection of human rights and freedoms, the independence, impartiality, expertise, equality and dignity of the judicial office. Moreover, the code is intended to raise awareness of personal and professional responsibility, conscientiousness and efficiency in performing the judicial office. Croatian judges emphasized that they seek to continuously develop and improve mutual human relations amongst judges as well as their relations with employees and participants of court proceedings and to promote the principle of high ethical standards. For the society judicial ethics in Croatia aims to provide lawful and prompt legal protection to citizens, legal entities, and all other authorized participants of court proceedings; and as it is established in international standards, it aims to strengthen the trust of the public in the fairness and efficiency of the judicial profession. ${ }^{20}$

By establishing the Code of Ethics in 2004, Estonian judges proclaimed that they are: 1 ) bearing in mind that impartiality, independence and integrity of judges are to be unconditionally guaranteed in the rule of law; 2) considering that Estonia must observe the principles of fair trial and the practice of good conduct of judges and legal traditions developed in the world; 3) aware of the need to meet the standards set to the activities and qualification requirements of judges; 4) taking into consideration that judges have a central role in safeguarding democracy and legal order; 5) bearing in mind that high professional level and flawless conduct of judges constitute a condition and a guarantee of high authority of the court and administration of justice; 6 ) considering that judges have been empowered to decide on life and freedom, rights, obligations and property of people; 7) bearing in mind that the mission of the courts is to serve the people; and 8) aware of the high moral and legal responsibility resting on judges. ${ }^{21}$ These social and political preconditions for the codified judicial ethics in Estonia are very different than the situation in Denmark ten years later. In Denmark, while adopting guiding ethical principles for judges in 2014, the Association of Danish Judges just paid attention to the fact that the Danish courts enjoy the highest degree of trust among the population, which is essential in a democratic society. Therefore, to ensure this, and in the light of, inter alia, the Council of Europe's recommendation R(2010) 12 of 17 November 2010 on judges' independence, effectiveness and responsibility, the association decided to

\footnotetext{
${ }^{20}$ Code of Judicial Ethics of the Republic of Croatia, The Council of presidents of all councils of Judges of the Republic of Croatia (2006) // http://pak.hr/cke/propisi,\%20zakoni/en/CodeofJudicalEthics/EN.pdf.

21 Estonian Judges' Code of Ethics, The Court en banc (2004) // http://www.nc.ee/?id=682.
} 
write down the guiding ethical principles for judges. The principles are a codification of those already applicable to judges and they are a supplement to the legislation's general rules on courts' and judges' affairs. The principles do not repeat rules that in general are already imposed by law. ${ }^{22}$ Similarly to Denmark, the Ethical Principles for Norwegian judges adopted in 2011 in Norway aim at promoting such conduct among judges that generates and enhances public confidence in courts and court decisions. The principles also serve as a source of information to judges and users of the courts of what is considered to be proper conduct of judges. ${ }^{23}$ In Sweden the document "Good judicial practice: Principles and issues" aims to provide judges with guidance when dealing with the ethical dilemmas and problems they encounter in their daily work. It can help the judge to act in such a manner that the confidence of the general public in judges, the courts and their rulings is upheld and reinforced. The document can also provide the general public with essential information about views held by judges on basic ethical principles and current issues. Another aim of this code is to be used in a training context and can contribute to personal reflection, ensuring that discussions between judges regarding good judicial practice are kept alive. ${ }^{24}$

In the introduction of the Ethical Principles for Judges adopted in 2012 by the Association of Finnish Judges it is highlighted that the ethical principles correspond to the views of the Finnish judiciary at the time of their approval and are aimed at strengthening the public's trust in the administration of justice, informing the public about judicial ethics and helping judges to make ethically justified choices. More detailed objectives introduced in the Code of Ethics of Judges of the Republic of Lithuania of 2006, which generally establishes the purpose of determining the basic principles of conduct of judges and regulating the conduct of judges during the fulfilment of direct as well as indirect duties. The objectives of this code are: 1) to determine the principles of activities and conduct which are to be followed by a judge during the fulfilment of duties which are laid down by law and leisure time from the exercise of the direct duties; 2) to fix that justice and other universal human values take priority in the activities of the courts; 3 ) to enhance the trust of the public in courts and judges to increase their authority. ${ }^{25}$

\footnotetext{
22 Ethical Principles for Judges, The Association of Danish Judges (2014) // http://dommerforeningen.dk/english/ethical-principles-for-judges/.

${ }^{23}$ Ethical Principles for Norwegian Judges, The Norwegian Association of Judges (2010) // http://www.coe.int/t/dghl/cooperation/CCJE/cooperation/Ethical\%20_principles_Norwegian_judges.pdf. ${ }^{24}$ Good Judicial Practice. Principles and Issues, Swedish association of judges and Courts of Sweden (2013) //

http://www.domstol.se/Publikationer/Rapporter/god_domarsed-grundsatser_och_fragor_eng.pdf.

${ }^{25}$ Code of Ethics of Judges of the Republic of Lithuania, The General meeting of the Lithuanian judges (2006) //

http://www.judicial-ethics.umontreal.ca/en/codes\%20enonces\%20deonto/documents/Code_lituanie.pdf.
} 
The development of ethical values is emphasized in the Code of Ethics for Members of the Judiciary of Malta of the year 2004. This code sets the codification for members of the Judiciary to have a Code of Ethics regulating their conduct and providing them with guidelines that expressly confirm the values they have always adhered to. These values are brought to the notice of the public so as to strengthen trust in the administration of justice. It is emphasized that trust cannot be maintained and reinforced if members of the judiciary do not adhere to this code, if they fail to observe the highest standards of correct ethical behaviour, and if the state does not ensure that the judiciary has at its disposal all the necessary means and resources to enable it to carry out its duties efficiently and within a reasonable time. ${ }^{26}$

In the Netherlands the Code of Conduct for judicial personnel ${ }^{27}$ aims to further substantiate the mission of the Judiciary and is a concise document which elaborates the core values, namely: independence, autonomy, impartiality, expertise and professionalism, and integrity. It does not reiterate rules of conduct that are dealt with by the law or other rules. The last code in the Netherlands is the NVVR Guide to Judicial Conduct of the Dutch Judges Association ${ }^{28}$ which was drawn up and adopted in 2011. It provides practical guidance to judges for their actions and behaviour and aims to explain the society how judges deal with integrity issues.

The Romanian Deontological Code for Judges and Prosecutors adopted in 2005 establishes the standards for their conduct according to the honour and dignity of their profession. Provisions included in this code present criteria for the evaluation of the efficiency of their activity as well as for the integrity of judges and prosecutors. ${ }^{29}$ A softer approach to judicial ethics is presented in the Statement of Principles of Judicial ethics for the Scottish Judiciary adopted in 2010, which gives guidance, in the light of which judges will make their own decisions. It does not provide an answer to every ethical question with which a judge may be confronted nor does it prescribe a code of conduct. It allows the government to inform the public of the principles by which judicial office holders are guided in their professional and private lives. ${ }^{30}$ In England and Wales, a Guide to Judicial Conduct was adopted in 2013. It

${ }^{26}$ Code of Ethics for Members of the Judiciary in Malta, The Commission for the administration of Justice (2004) // www.judiciarymalta.gov.mt/code-of-ethics.

27 The Code of Conduct for Judicial Personnel; in: Matters of Principle. Codes on the Independence and Impartiality of the Judiciary (The Dutch Foundation 'Judges for Judges') // https://www.rechtspraak.nl/SiteCollectionDocuments/Matters-of-principle.pdf.

${ }^{28}$ NVVR Guide to Judicial Conduct of the Dutch Judges Association; in: Matters of Principle. Codes on the Independence and Impartiality of the Judiciary (The Dutch Foundation 'Judges for Judges') // https://www.rechtspraak.nl/SiteCollectionDocuments/Matters-of-principle.pdf.

29 Deontological Code for Judges and Prosecutors, Superior Council of Magistracy of Romania (2005) // www.csm1909.ro/csm/linkuri/15_11_2005_2048_en.doc.

30 The Statement of Principles of Judicial ethics for the Scottish Judiciary (2010) // http://www.scotlandjudiciary.org.uk/Upload/Documents/StatementofPriciplesofJudicialEthicsfortheScottishJudiciary.pdf. 
is intended to offer assistance to judges on issues rather than to prescribe a detailed code and to set up principles on the basis of which judges can make their own decisions and so maintain their judicial independence. ${ }^{31}$

Differently from the above-mentioned examples on objectives of judicial ethics in European countries, in Slovenia, the preamble of the Code of Judicial ethics ${ }^{32}$, which was adopted in 2001, states its aim is to fulfill the mission imposed by the Constitution and law as well as to contribute as successfully as possible to protecting and strengthening constitutionality and legality, and to specify in more detail the extent and content of judges' duties in performing the judicial function. It also seeks to assist in molding the character of judges as highly professional, independent, impartial and personally irreproachable holders of judicial authority. Judges are bound to behave according to the principles of the Code of Judicial Ethics. It contains professional and personal rules, which are enshrined in the form of principles and are based on the general standpoint that judges, both individually and collectively, must respect the honour and reputation of the judicial service and endeavour to strengthen public confidence in the judiciary. The code is formed in such a way that in all principles it protects the various aspects of judicial independence, impartiality and efficiency, which are crucial for the right of everyone to fair, just and effective legal protection. The code defines the activity and behaviour of judges. It also contains only the most important ethical principles, but judges must behave according to generally recognized ethical standards as well. In the preamble of the Ethical Code of Judicial Conduct in Slovakia ${ }^{33}$ adopted in 2010, the significance of the code for an increased public trust in judiciary, the protection of human rights and the enhancement of the idea of a legal state, and the prevention and control of corruption in the judiciary are emphasized.

By summarizing the objectives of judicial ethics in different European countries and judicial institutions it can be deduced that judicial ethics is dedicated not only to the judges themselves but also to other members of society, to the legislative and executive power and to the general public. First of all, judicial ethics gives recommendations and guidelines to judges about how to deal with ethical dilemmas and establishes appropriate standards of judicial conduct. It also offers ethical principles for judges that supplement laws on courts. Establishing standards for ethical conduct of judges and providing guidance to judges is a self-governing

\footnotetext{
31 Guide to Judicial Conduct, The Judges' Council of England and Wales (2013) // https://www.judiciary.gov.uk/wp-content/uploads/JCO/Documents/Guidance/judicial_conduct_2013.pdf. 32 The Code of Judicial Ethics of Slovenia, The Association of Judges of the Republic of Slovenia (2001) // http://www.judicial-ethics.umontreal.ca/en/codes\%20enonces\%20deonto/documents/SLOVENIACODEOFJUDICIALETHICS.pdf.

33 The Ethical Code of Judicial Conduct, The Judicial Council of the Slovak Republic (2010) // http://www.sudcovia.sk/sk/dokumenty/legislativa/39-english-categories/documents/archive/401-theetcodeofju-cond.
} 
instrument for the judges themselves. By adopting judicial ethics, judges undertake to obey its requirements and voluntarily admit the requirements of the peculiarities of their social status. Furthermore, by recognizing ethical rules, judges, as judicial power, not only establish a framework regulating judicial conduct but also encourage fundamental cultural values, which are essential for judiciary in administering justice.

Secondly, judicial ethics assists the legislative and executive power to better understand the specificity and sensitivity of judicial activity. It is very important for the implementation of the principle of separation of powers, cooperating between state powers and especially in judicial processes which are somehow connected to politics. For the state under the rule of law it is essential to respect the principle of separation of powers. Therefore, legislative and executive powers should not only act in respect of ultra vires doctrine but also in respect of judicial ethics. They should be introduced to the content of principles of judicial ethics and to the main values of how judicial power is executed. Judicial ethics, by expressing the contest of values and principles of the judiciary, makes it possible for the official representatives of others state powers to draw the correct line of the boundaries of legitimacy of their activity in compliance with the doctrine of separation of powers.

Thirdly, for the general public judicial ethics should help to ensure the confidence of this professional power and help to understand the specificity of proceedings. The confidence of the judiciary in the administration of justice is a prerequisite for the effectiveness of courts' activity. Therefore, it is of high importance to take all possible measures to increase and not to lose the existing degree of trust among the general public and the judicial ethics is the correct way of doing that. Finally, judicial ethics establishes a culture of litigation and clarifies the methods of implementation of procedural norms. Judicial ethics in tandem with the ethics of attorneys, prosecutors and general lawyers, ensures not just procedural justice, but the effectiveness of the whole legal justice system. Thus, the objectives of judicial ethics are very complex and should be oriented to systematic results.

For the objectives of judicial ethics to be implemented, one must find the best ways to establish it in the legal system. As a system of values judicial ethics lives in the system of every national or international judiciary, every court, every panel or even separately in every judge. But as a set of rules of professional conduct it should be expressed objectively that professional communities would have the possibility to be acquainted with it. Therefore, the ways in which judicial ethics is established is the next section of the article. 


\section{EUROPEAN PRACTICES OF ESTABLISHING JUDICIAL ETHICS}

Judicial ethics as a separate self-governing institute and a set of ethical norms does not have old traditions in the civil law system. In many U.S. states, however, codes of judicial conduct were promulgated a long time ago. The first code of legal ethics was elaborated and adopted by the Alabama State Bar Association in 1887. ${ }^{34}$ In Europe codes of judicial ethics are a relatively new phenomenon. Processes of globalization and the increased variety of social and economic institutions have not surpassed the judiciary. Globalization of the judiciary was one of the main factors which led to the international unification of judicial ethics and was a prerequisite for the further developments. These processes inspired many European countries to revise their internal judicial systems in relation to judicial ethics. The Judicial Group on Strengthening Judicial Integrity of the United Nations Office at the second meeting which was held in Bangalore, India, in February of 2001, formulated the relevant principles, and agreed on the Bangalore Draft Code of Judicial Conduct. The Bangalore Draft was disseminated widely among judges of both common law and civil law systems from over 75 countries. There was a significant agreement among judges of the common law and the civil law systems concerning core values, but there was some disagreement as well. One of them was a concern expressed by civil law judges on the use on the use of the word "code", which legal professionals in continental Europe usually understand as a legal instrument that was complete and exhaustive, particularly since standards of professional conduct were different from statutory and disciplinary rules. ${ }^{35}$ Additionally, there were few more arguments found against judicial ethics codes. One was that judicial independence can be jeopardized by the imposition of a code of conduct from outside the judiciary and that such a code could be used by superior courts to control dissents and differences in judgements by lower courts. ${ }^{36}$ Nevertheless some dangers could be perceived; but it could come from improper implementation and usage of codes of judicial ethics rather than of codified ethical norms themselves.

A comparative analysis of the practices establishing judicial ethics in different European countries reaffirms the importance for the administration of justice. This primary data presents the recent evolutionary developments of this institute. The analysis shows differences within the establishments of judicial ethics in European countries. Not all European countries have codification of judicial ethics, other have guidelines, declarations, booklets, principles, good judicial practice. Table No. 1

\footnotetext{
34 Jörg Philipp Terhechte, supra note 4: 506.

${ }^{35}$ Commentary on the Bangalore Principles of Judicial Conduct, supra note 10: 15.

${ }^{36}$ Emilio J. Cárdenas and Héctor M. Chayer, "Corruption, accountability and the discipline of judges in Latin America," Global Corruption Report // http://unpan1.un.org/intradoc/groups/public/documents/undpadm/unpan045153.pdf
} 
(see below) presents the collected data that shows the current situation of legal status of judicial ethics in different legal systems. It also includes the name of a document (or regulation) of judicial ethics as well as the institution and the year of adoption of judicial ethics in different European countries.

Judicial ethics as a set of the fundamental principles of the statute for judges is set out in internal norms at the highest level in each European state. But not in every legal system is judicial ethics recognized at the legislative level. Legal grounds to adopt the code of judicial ethics are established in laws of Bulgaria, Croatia, Estonia, Italy, Lithuania and Malta (in Constitution). Most often, the law on courts only empowers self-governing judicial institutions to adopt the code of ethics of judges. For example, Article 30 (1) of the Judiciary System Act of Bulgaria states that in order to discharge the powers specified by the Constitution, the Supreme Judicial Council shall endorse rules of professional ethics. The Law on courts of Croatia states that the Code is accepted by the Council composed of the Presidents of all Judicial Councils in the Republic of Croatia (Article 107 Part 2) and the Assembly is obliged to issue the code of court ethics within the period of six months after the law is brought into force (Article 157 Part 3). Article 38 of Courts Act of Estonia empowers the Court en banc to approve the code of ethics of judges. The Law of the Republic of Lithuania on Courts delegates the competence to the General Meeting of Judges to approve the Code of judicial ethics.

In most European Countries Judicial ethics is established by the judiciary selfgoverning bodies: the Belgian High Council of Justice, the Supreme Judicial Council of Bulgaria, the Council composed of the presidents of judges of the Republic of Croatia, the Court en banc, which is comprised of all Estonian judges, the Conference of Judges of Georgia upon the recommendation of the High Council of Justice of Georgia, the French High Council, the National Judicial Council of Hungary, the Conference of Judges of the Republic of Latvia, the General meeting of the Lithuanian Judges, the Commission for the administration of Justice of Malta, the Dutch Council for the Judiciary and the President's Council, the National Council of the Judiciary of Norway, the Superior Council of Magistracy of Romania, the Judicial Council of the Slovak Republic, the Plenary Session of the General Council of the Judiciary and the Judges' Council of England and Wales. But there are countries where the documents on Judicial ethics are adopted by professional judicial associations: The Association of Austrian Judges, the general meeting of the Association of Danish Judges, the Association of Finnish Judges, the National Association of Judges in Italy, the Dutch Association for the Judiciary, the Norwegian Association of Judges, the Association of Judges of the Republic of Slovenia and the Swedish association of judges and Courts. A unique feature is that 
judicial ethics is not established in any of the countries by legislative, executive or another state power except the judiciary itself. Norms of judicial ethics are adopted by the principle "judges to judges," and by no means are adopted from the outside. This is in compliance with the nature of judicial ethics as a self-governing tool to foster values of the judiciary, to determine the standard of conduct of judges and to show the society the peculiarity of the administration of justice.

Table No. 1

\begin{tabular}{|c|c|c|c|}
\hline Country & $\begin{array}{c}\text { Legal status of Judicial } \\
\text { ethics }\end{array}$ & $\begin{array}{c}\text { Name of regulation of } \\
\text { Judicial ethics }\end{array}$ & $\begin{array}{l}\text { Institution and year of } \\
\text { adoption } \\
\text { Other sources } \\
\text { (recommendations, } \\
\text { opinions, etc.) }\end{array}$ \\
\hline Austria & No data & $\begin{array}{l}\text { The Wels Declaration } \\
\text { of Ethics. } \\
\text { Declaration of Judicial } \\
\text { ethics. }\end{array}$ & $\begin{array}{l}\text { Adopted by the } \\
\text { Association } \\
\text { Austrian Judges on } \\
\text { November 8th, } 2007 .\end{array}$ \\
\hline Belgium & $\begin{array}{l}\text { The booklet has no } \\
\text { force of law and } \\
\text { contains only } \\
\text { recommendations on } \\
\text { the conduct desired of } \\
\text { judges and prosecutors } \\
\text { in their professional } \\
\text { and private live. }\end{array}$ & $\begin{array}{l}\text { The booklet "Guide } \\
\text { for magistrates, } \\
\text { principles, values and } \\
\text { qualities". }\end{array}$ & $\begin{array}{l}\text { Adopted by the } \\
\text { Belgian High Council } \\
\text { of Justice in } 2012 \text {. }\end{array}$ \\
\hline Bulgaria & $\begin{array}{l}\text { A code was adopted on } \\
\text { the grounds of Article } \\
30(1)(12) \text { of the } \\
\text { Judiciary System Act. }\end{array}$ & $\begin{array}{l}\text { A Code of Ethics for } \\
\text { the Behaviour of } \\
\text { Bulgarian Magistrates. }\end{array}$ & $\begin{array}{l}\text { Adopted in } 2009 \text { by a } \\
\text { decision of the } \\
\text { Supreme Judicial } \\
\text { Council. }\end{array}$ \\
\hline Cyprus & No data & $\begin{array}{l}\text { Absence of the code } \\
\text { of Judicial ethics. }\end{array}$ & $\begin{array}{l}\text { Standards exist on } \\
\text { recruitment in order } \\
\text { to ensure the high } \\
\text { moral of the future } \\
\text { judge noted in } \\
\text { practice as a lawyer. }\end{array}$ \\
\hline Croatia & $\begin{array}{l}\text { The Code was adopted } \\
\text { on the grounds of } \\
\text { Articles } 107 \text { and } 157 \text { of } \\
\text { the Law on courts. The } \\
\text { law states that the } \\
\text { Assembly is obliged to }\end{array}$ & $\begin{array}{l}\text { The Code of Judicial } \\
\text { ethics. }\end{array}$ & $\begin{array}{l}\text { Adopted in } 2006 \text { by } \\
\text { the Council of } \\
\text { presidents of all } \\
\text { councils of Judges of } \\
\text { the Republic of } \\
\text { Croatia. }\end{array}$ \\
\hline
\end{tabular}




\begin{tabular}{|c|c|c|c|}
\hline & $\begin{array}{l}\text { issue the code of court } \\
\text { ethics. }\end{array}$ & & \\
\hline $\begin{array}{l}\text { Czech } \\
\text { Republic }\end{array}$ & No data & $\begin{array}{l}\text { Ethical Principles of } \\
\text { the Conduct of } \\
\text { Judges. }\end{array}$ & $\begin{array}{l}\text { Adopted in } 2005 \text { by } \\
\text { the Union of Judges of } \\
\text { the Czech Republic. }\end{array}$ \\
\hline Denmark & $\begin{array}{l}\text { Administration of } \\
\text { Justice Act provides } \\
\text { basic guidance. }\end{array}$ & $\begin{array}{l}\text { Ethical principles for } \\
\text { judges. }\end{array}$ & $\begin{array}{l}\text { Adopted at the } \\
\text { general meeting of } \\
\text { the Association of } \\
\text { Danish Judges on } 24 \\
\text { October } 2014 .\end{array}$ \\
\hline Estonia & $\begin{array}{l}\text { The Code was adopted } \\
\text { on the grounds of } \\
\text { Articles } 38 \text { of the } \\
\text { Courts Act. }\end{array}$ & $\begin{array}{l}\text { The Code of Ethics of } \\
\text { Estonian judges. }\end{array}$ & $\begin{array}{l}\text { Adopted on February } \\
13,2004 \text {, the Court } \\
\text { en banc, which is } \\
\text { comprised of all } \\
\text { Estonian judges. }\end{array}$ \\
\hline Finland & No data & $\begin{array}{l}\text { Ethical Principles for } \\
\text { Judges. }\end{array}$ & $\begin{array}{l}\text { Adopted in } 2012 \text { by } \\
\text { the Association of } \\
\text { Finnish Judges. }\end{array}$ \\
\hline France & No data & $\begin{array}{l}\text { Guidelines of ethical } \\
\text { obligations. }\end{array}$ & $\begin{array}{l}\text { Adopted in } 2010 \text { by } \\
\text { the French High } \\
\text { Council. }\end{array}$ \\
\hline Germany & $\begin{array}{l}\text { References to how } \\
\text { judges are to conduct } \\
\text { themselves ethically } \\
\text { are to be found in the } \\
\text { Basic Law, in the } \\
\text { German Judiciary Act } \\
\text { and in the respective } \\
\text { judiciary acts of the } \\
\text { German Länder. } \\
\text { German Judiciary Act in } \\
\text { the version of the } \\
\text { promulgation of } 19 \\
\text { April } 1972 \text { (Federal Law } \\
\text { Gazette Part I p. } 713 \text { ), } \\
\text { last amended by Article } \\
9 \text { of the Act of February } \\
5,2009 \text {. }\end{array}$ & $\begin{array}{l}\text { Absence of a code of } \\
\text { ethics. }\end{array}$ & No data \\
\hline Georgia & Article 65 of Organic & Judges Ethics Code. ${ }^{38}$ & Adopted \\
\hline
\end{tabular}




\begin{tabular}{|c|c|c|c|}
\hline & $\begin{array}{l}\text { Law of Georgia on } \\
\text { Common Courts } 37 \\
\text { delegates to the } \\
\text { Conference of Judges of } \\
\text { Georgia to approve } \\
\text { rules of judicial ethics } \\
\text { upon the } \\
\text { recommendation of the } \\
\text { High Council of Justice } \\
\text { of Georgia. }\end{array}$ & & $\begin{array}{l}\text { conference of Judges } \\
\text { of Georgia in } 2012 \text {. }\end{array}$ \\
\hline Hungary & No data & $\begin{array}{l}\text { The Code of Judicial } \\
\text { Conduct. }\end{array}$ & $\begin{array}{l}\text { Adopted on November } \\
10,2014 \text { by the } \\
\text { National Judicial } \\
\text { Council. }\end{array}$ \\
\hline Ireland & $\begin{array}{l}\text { Judges are obliged to } \\
\text { act in compliance with } \\
\text { the Ethics in Public } \\
\text { Office Act } 1995 \text { and } \\
\text { with the Standards in } \\
\text { Public Office Act } 2001 .\end{array}$ & $\begin{array}{l}\text { Absence of a code of } \\
\text { ethics. }\end{array}$ & No data \\
\hline Italy & $\begin{array}{l}\text { In 1993, upon } \\
\text { delegation from the } \\
\text { Parliament, the Italian } \\
\text { Government issued a } \\
\text { decree according to } \\
\text { which all the branches } \\
\text { of the civil service } \\
\text { should adopt codes of } \\
\text { ethics in order to } \\
\text { ensure a high standard } \\
\text { of services to the } \\
\text { citizens. }\end{array}$ & $\begin{array}{l}\text { The Code of Judicial } \\
\text { ethics. }{ }^{39}\end{array}$ & $\begin{array}{l}\text { Adopted in } 1994 \text { by } \\
\text { the } \\
\text { Association of Judges. }\end{array}$ \\
\hline Latvia & No data & $\begin{array}{lll}\text { Code of Judicial } \\
\text { ethics. }\end{array}$ & $\begin{array}{l}\text { Adopted in } 1995 \text { by } \\
\text { the Conference of } \\
\text { Judges of the Republic } \\
\text { of Latvia. }\end{array}$ \\
\hline Lithuania & Article 117 of Law on & The Code of ethics of & Adopted in 2006 by \\
\hline
\end{tabular}

38 Judges Ethics Code, Adopted in 2012 by Association of Georgian Judges //

http://www.supremecourt.ge/eng/judges-self-governance/judges-ethics-code/.

37 Organic Law of Georgia on Common Courts //

https://matsne.gov.ge/en/document/download/90676/13/en/pdf.

39 The Code of Judicial Ethics in Italy, Adopted in 1994 by the National Association of Judges //

http://www.judicial-

ethics.umontreal.ca/en/codes\%20enonces\%20deonto/documents/CODE_ITALIEN.pdf. 


\begin{tabular}{|c|c|c|c|}
\hline & $\begin{array}{l}\text { Courts established the } \\
\text { duty for the General } \\
\text { Meeting of Judges to } \\
\text { approve the Code of } \\
\text { Judicial ethics. }\end{array}$ & $\begin{array}{l}\text { the judges of the } \\
\text { Republic of Lithuania. }\end{array}$ & $\begin{array}{l}\text { the General meeting } \\
\text { of the Lithuanian } \\
\text { judges. }\end{array}$ \\
\hline Malta & $\begin{array}{l}\text { Article } 101 \mathrm{~A}(11)(\mathrm{d}) \text { of } \\
\text { the Constitution of } \\
\text { Malta directs the } \\
\text { Commission for the } \\
\text { Administration of } \\
\text { Justice to "draw up a } \\
\text { code or codes of ethics } \\
\text { regulating the conduct } \\
\text { of members of the } \\
\text { judiciary". }\end{array}$ & $\begin{array}{l}\text { The Code of Ethics for } \\
\text { Members of the } \\
\text { Judiciary. }\end{array}$ & $\begin{array}{l}\text { Adopted in } 2004 \text { by } \\
\text { the Commission for } \\
\text { the administration of } \\
\text { Justice. }\end{array}$ \\
\hline Netherlands & No data & $\begin{array}{l}\text { The Code of Conduct } \\
\text { for the Judiciary. } \\
\text { The NVvR's Guide to } \\
\text { Judicial Conduct } \\
\text { Judicial Impartiality } \\
\text { Guidelines }\end{array}$ & $\begin{array}{l}\text { Adopted by the Dutch } \\
\text { Council for the } \\
\text { Judiciary and the } \\
\text { President's Council in } \\
2010 . \\
\text { Adopted by the } \\
\text { Members' Council of } \\
\text { the NVvR in } 2011 \text {. } \\
\text { Laid down in March } \\
\text { 2004 by the } \\
\text { Netherlands } \\
\text { Association for the } \\
\text { Judiciary and the } \\
\text { Dutch Assembly of } \\
\text { Court Presidents. The } \\
\text { guidelines are } \\
\text { endorsed by the } \\
\text { administrative bodies } \\
\text { of the courts in the } \\
\text { Netherlands, the } \\
\text { President of and the } \\
\text { Procurator General at } \\
\text { the Supreme Court, } \\
\text { the Netherlands } \\
\text { Association for the }\end{array}$ \\
\hline
\end{tabular}




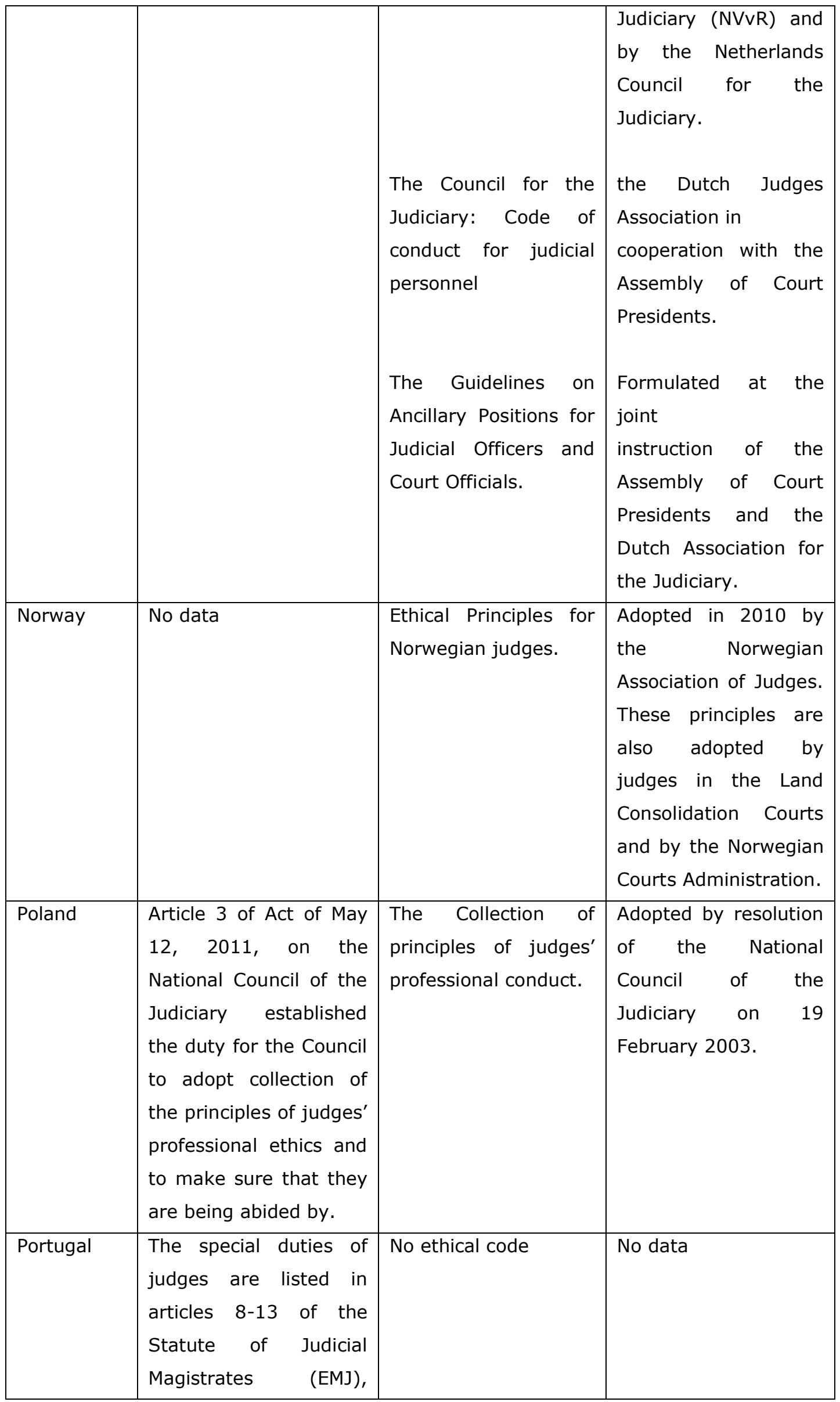




\begin{tabular}{|c|c|c|c|}
\hline & $\begin{array}{l}\text { approved by Law No. } \\
21 / 85 \text {, of } 30.07 \text {. }\end{array}$ & & \\
\hline Romania & No data & $\begin{array}{l}\text { Deontological code for } \\
\text { judges and } \\
\text { prosecutors. }\end{array}$ & $\begin{array}{lll}\text { Adopted in } 2005 & \text { by } \\
\text { Superior Council of } & \text { of } \\
\text { Magistracy } & \text { of } \\
\text { Romania. } & \end{array}$ \\
\hline Slovakia & No data & $\begin{array}{l}\text { The ethical code of } \\
\text { Judicial conduct. }\end{array}$ & $\begin{array}{l}\text { Adopted in } 2010 \text { by } \\
\text { the Judicial Council of } \\
\text { the Slovak Republic. }\end{array}$ \\
\hline Slovenia & No data & $\begin{array}{l}\text { The Code of Judicial } \\
\text { ethics. }\end{array}$ & $\begin{array}{l}\text { Adopted in } 2001 \text { by } \\
\text { the Association of } \\
\text { Judges of the Republic } \\
\text { of Slovenia. }\end{array}$ \\
\hline Spain & No data & No ethical code & $\begin{array}{l}\text { Agreement of the } \\
\text { Plenary Session of the } \\
\text { General Council of the } \\
\text { Judiciary (CGPJ) of } \\
\text { 25/02/2016: The } \\
\text { Plenary Session of the } \\
\text { CGPJ agreed to } \\
\text { adhere to the } \\
\text { principles of the } \\
\text { Ibero-American Code } \\
\text { of Judicial ethics, } \\
\text { since the Spanish } \\
\text { judiciary has not } \\
\text { approved its own code } \\
\text { of ethics. }\end{array}$ \\
\hline Sweden & No data & $\begin{array}{lr}\text { "Good } & \text { judicial } \\
\text { practice. } & \text { Principles } \\
\text { and issues". } & \end{array}$ & $\begin{array}{l}\text { The document is } \\
\text { established by } \\
\text { Swedish association of } \\
\text { judges and Courts of } \\
\text { Sweden. }\end{array}$ \\
\hline $\begin{array}{l}\text { England } \\
\text { and Wales }\end{array}$ & No data & $\begin{array}{l}\text { Guide to Judicial } \\
\text { Conduct. }\end{array}$ & $\begin{array}{l}\text { Published by the } \\
\text { Judges' Council, } \\
\text { October } 2004 \text {. }\end{array}$ \\
\hline Scotland & & $\begin{array}{l}\text { The Statement of } \\
\text { Principles of Judicial } \\
\text { ethics for the Scottish } \\
\text { Judiciary. }\end{array}$ & $\begin{array}{l}\text { Framed in 2010, } \\
\text { drafted by a working } \\
\text { group of judges under } \\
\text { the chairmanship of } \\
\text { The Rt. Hon Lord }\end{array}$ \\
\hline
\end{tabular}




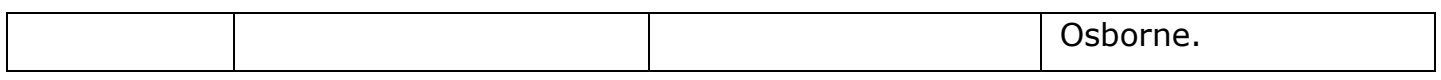

Current documental analyses lead to the conclusion that the best practice of European countries is that the legal grounds to adopt the code of judicial ethics are established in laws. The way law imposes an adoption of ethical norms as a normative act might vary: empowering the judicial body to establish ethical norms or just to establish general legal grounds or obligation to act in compliance with judicial ethics. Nevertheless, in all European states norms of judicial ethics are based on the principle "judges to judges", because the nature of judicial ethics is a self-governing institution. Most of the European countries have codified judicial ethics by adopting special documents: codes, guidelines, declarations, booklets, principles, good judicial practice, etc. But there are still some of them for which judicial ethics is a part of judicial tradition and basic requirements of laws on courts. The global tendency to adopt the codes of judicial ethics requires the author to summarize the main principles of already existing codes of judicial ethics and to try to find general structure that could be used when constructing a new code.

\section{THE BASIC PRINCIPLES OF THE CODES OF JUDICIAL ETHICS AND THEIR STRUCTURE}

Ethical principles reflect the core values of the judiciary and provide a soul to the conduct of court and to individual judges. Ethics means an intention to make well, with the aim of the common good in the exercise of a task. ${ }^{40}$ It is a process; not something static. Ethical principles incarnate constitutional and lawful obligations of judges and describe the ways they must be administered. In addition, the principles set the standards of professional activity for judges and describe main features of a professional judge. Finally, they explain clearly to the society the way justice is administered, seeking the confidence for judges in individual cases and for the courts and judiciary in general. The systematic construction of ethical norms is one of the main issues that countries face while establishing documents on judicial ethics. The Bangalore Principles of Judicial Conduct presented after the preamble entail six main principles of Judicial Conduct: Independence; Impartiality; Integrity; Propriety; Equality; Competence and Diligence. The comparative study of European practices reveals differences in the amount and content of separate principles that are expressed in codes or other documents of judicial ethics. The scope of this article does not allow the author disclose the differences of the content of each of the principles in different European countries. The content of

40 Eric J. Maitrepierre, "Ethics, Deontology, Discipline of Judges and Prosecutors in France" // http://www.unafei.or.jp/english/pdf/RS_No80/No80_29VE_Maitrepierre.pdf. 
judicial ethics requires constant and continuing comparative research, because the permanent rise of new judicial ethical dilemmas leads to renewable contents. In this article, the author sets the goal to make a comprehensive list of principles of judicial ethics that enables developers of judicial ethics to test existing regulation and to improve possible reforms. Therefore, below the article treats the practice of establishments of separate principles of judicial ethics in already adopted documents of Europe.

Resolution on Judicial ethics of European Court of Human Rights offers the following principles to the members of the court and, where relevant, to former judges and ad hoc judges: Independence; Impartiality; Integrity; Diligence and competence; Discretion and Freedom of expression. Exclusive right to advise judges on these principles in case of doubt of application in a concrete situation is given to the President of the Court.

In Belgium the booklet Guide for magistrates, principles, values and qualities $^{41}$ contains the fundamental values which have been identified and which are essential for the judiciary: Independence; Impartiality; Integrity; Prudence and discretion; Diligence; Respect and the ability to listen to others as well as Equality of treatment and competence. Judges also must possess other qualities: wisdom; loyalty, humanity, courage, diligence and caution, good listening, communication skills and open-mindedness.

The Code of Judicial ethics in the Republic of Croatia sets forth these principles: Constitutionality and legality; Humanity and ethics; Independence; Impartiality; Expertise; Equality; Dignity of the judicial profession; Responsibility; Diligence; Freedom of association; Relation to the public; Relations towards judges and employees at the court. The document Ethical principles for judges of the Association of Danish Judges has established these six principles: Independence; Impartiality; Integrity; Quality; Openness and Accountability. As it is emphasized in this document, the principles are a codification of those already applicable to judges and they are a supplement to the legislation's general rules on courts' and judges' affairs. These ethical principles are taken up for discussion and possible revision on an ongoing basis, including in the light of the development of society and Denmark's international obligations.

Ethical norms within The Code of Ethics of Estonian Judges are not named as principles of judicial ethics but are established as ethical provisions. It consists of general provisions (10 items) and three groups of special provisions: Courts and court procedure ( 9 items); Independence and impartiality ( 7 items) as well as

\footnotetext{
${ }^{41}$ Guide for Magistrates, Principles, Values and Qualities, Published in 2012 by the Belgian High Council of Justice //

http://www.csj.be/sites/default/files/press_publications/o0023f.pdf.
} 
Extra-judicial activities (6 items). General provisions determine essential ethical obligation for judges to preserve the reputation of integrity and independence of the judiciary and to fulfil the functions of his or her office impartially without selfinterest, carefully, and in the best possible way. It sets a duty to a judge to arrange his or her life and activities, including legal activities, so that the threat of a possible conflict with his or her judicial duties is minimal. It establishes the legal grounds and prohibitions of judges' activities outside the court: for example, opportunities for a judge to be engaged in law creation and improvement of the legal and judicial system or in teaching and research, but his or her refraining from political activities. It is worth mentioning the regulation that the requirements of professional ethics shall be interpreted on the basis of law, decisions of the judges' disciplinary chamber, the established practice among the judiciary as well as the opinions of senior colleagues and the conscience of judges.

The Code of Judicial Ethics in Italy is divided into three parts: 1. General principles; 2. Independence, impartiality and correctness; 3. Judge's conduct while exercising his/her functions. First part establishes fundamental values and principles coded therein are as follows: dignity, correctness and respect for the public interest; personal unselfishness, independence and impartiality; relations to citizens and justiciability; respect for the personality and the dignity of each one; rejection of any kind of pressure; duties of activity and improvement of their own professionalism; use of the means and resources pertaining to the administration of Justice; prohibition of using professional information for non-institutional aims; relationships with the press and other mass media; membership of association. The second part consists of articles on the independence of judges and public prosecutors, the impartiality of judges and public prosecutors and the duty of correctness. The third part involves not only rules on conduct inside the courtroom, but also on judge's conduct in general and, differently from other European countries, it establishes special duties of the heads of jurisdictions.

Code of Judicial Ethics for Latvian Judges ${ }^{42}$ has five articles which consist of special ethical fields: 1 . A judge shall hold in respect his position, independence of judiciary and integrity of court; 2. A judge shall avoid impropriety and the appearance of impropriety in the activities; 3. A judge shall perform the duties of the office impartially and diligently; 4 . A judge shall regulate extra-judicial activities in such a manner that there is no conflict with judicial duties; 5 . A judge or judge's candidate refrains from political activity.

\footnotetext{
42 Code of Judicial Ethics, Adopted in 1995 by the Conference of Judges of the Republic of Latvia // http://webcache.googleusercontent.com/search?q=cache:TquFvYQa1V0J:at.gov.Iv/files/uploads/files/arc hive/department1/tiesnesu_etikas_kodekss_eng.doc $\& \mathrm{~cd}=1 \& \mathrm{hl}=|\mathrm{t} \& \mathrm{ct}=\mathrm{clnk} \& \mathrm{gl}=| \mathrm{t}$.
} 
The Code of Ethics of the Judges of the Republic of Lithuania is one of the most comprehensive and well-structured codes. This code determines the basic principles of conduct of judges of the Republic of Lithuania and regulates the conduct of judges during the performance of direct as well as indirect duties. The code has three chapters: general provisions, basic principles of conduct of judges and final provisions. There are twelve basic principles of conduct of judges presented there: 1 . Respect for human; 2 . Respect and loyalty for the State; 3. Justice and impartiality; 4. Independence; 5. Confidentiality; 6. Transparency and publicity; 7. Honesty and selflessness; 8. Decency; 9. Exemplarity; 10. Dutifulness; 11. Solidarity; 12 . Improvement of qualification. Each of these principles has from two to twelve rules that a judge shall observe. In the final provisions of the code, which are very important for enforcement, it is stated that judges voluntarily admit the requirements of their social status and undertake to obey the requirements of the code.

In the Netherlands, there are codes of ethics for judges and for court personnel as well. The Code of Conduct for Judicial Personnel drawn up by the Dutch Council for the Judiciary and the President's Council in 2010 established independence, autonomy, impartiality, integrity, expertise and professionalism as core values for the judiciary. The document Judicial Impartiality Guidelines gives ten recommendations on the following issues: 1 . Family and Relatives; 2. Acquaintances; 3. Additional Jobs of the Judge himself or herself; 4 . The (additional) Jobs of the (former) Spouse, (former) Partner or Close Relatives; 5. Substitute Judges; 6. Trainee Judicial Officers acting as Substitute Judge; 7. Previous Jobs; 8. Previous Involvement in a Case or in Parties; 9. Recommendation to the Courts concerning Further Arrangements; 10. Recommendation to the Courts concerning Further Enhancement of Impartiality. The last recommendation obliges the courts to ensure that judicial impartiality is regularly focused in relation to these guidelines and any supplements added by the courts. The Council for the Judiciary: Code of Conduct for Judicial Personnel establishes the following principles of conduct for judicial personnel in ancillary positions: impartiality and independence as well as incorruptibility and professionalism.

Ethical Principles for Norwegian Judges consist of these parts: 1. Basic requirements; 2. Independence; 3. Impartiality; 4. Integrity; 5. Equality; 6. Proper conduct; 7. Formulation of court decisions; 8. Discretion; 9. Competence; 10. Efficiency; 11 . Judges' relation to the media; 12 . Conduct of judges outside the role of a judge; 13 . Conduct of retired judges; 14 . Collegial intervention. It is important to note that retired judges should restrain from conduct that may be perceived as an inappropriate or unfortunate exploitation of the title of a judge. The 
last principle sets the rule that judges who become aware of violations of these ethical principles committed by colleagues should address this in a suitable way and intervene when substantial violations occur.

The Collection of Principles of Judges' Professional Conduct in Poland was adopted by a resolution of the National Council of the Judiciary on February 19, 2003. The Collection has three chapters: General principles, Principles of service and off-duty conduct, and 22 sections. The structure of the collection does not include separate values or ethical principles and, therefore, it could be considered too general. Nevertheless, in the sections there are rules of judicial ethics, for example, in General principles Article 2 determines that the judge shall always follow the rules of integrity, dignity, honour and sense of duty and shall always apply best practices. Principles of service in Article 11 states that the judge should explain procedural issues to parties and inform them about reasons of his decision in a way that shall be clear to them. While presenting reasons for his decision, the judge should avoid using phrases that go beyond the factual need for an explanation of the court's standpoint that could jeopardise the dignity or honour of persons involved in the case or third parties. Seeking effectiveness and implementation of the ethical behaviour established in the collection, in Article 5 it is determined that the judge should demand impeccable behaviour from other judges, observe the principles of professional ethics and should appropriately react to misconduct.

The Deontological Code for Judges and Prosecutors of Romania establishes the standards for their conduct in line with the honor and dignity of their profession. It consists of seven chapters: General provisions; Independence of justice; Promoting the supremacy of law; Impartiality of judges and prosecutors; Exercise of professional duties; Dignity and honour of the profession of a judge or a prosecutor; Activities incompatible with a judge or a prosecutor position.

The Statement of Principles of Judicial Ethics for the Scottish Judiciary establishes six main principles of judicial ethics: 1 . Judicial Independence; 2. Impartiality; 3. Integrity; 4. Propriety; 5. Equality; 6. Competence and Diligence. This is consistent with the structure and the components of the Bangalore Principles. The Statement gives guidance in the light of which judges will make their own decisions. As the Lord President has emphasized in its foreword, it does not provide an answer to every ethical question with which a judge may be confronted, nor does it prescribe a code of conduct. In the development of this document, importance has been attached to Bangalore Principles themselves and, therefore, acknowledgement is due to those responsible for their formulation. The 
guidance which follows from this document has been formulated particularly in the light of these sources and the relevant Scottish factors.

The Code of Judicial Ethics of the Republic of Slovenia is a catalogue of the most important principles by which every judge shall behave. The code has short description of principles and discloses them in the commentaries. The code establishes nine principles: 1 . Independence; 2 . Impartiality; 3 . Training; 4. Commitment; 5. Compatibility; 6. Incompatibility; 7. Discretion; 8. Attitude; 9. Reputation.

The Judicial Code of Slovakia establishes the general principles and a regulatory framework for judicial conduct in the performance of duties and avocational activities of judges. These general principles include: Independence; Impartiality; Fairness and transparency; Courtesy and tolerance; Incorruptibility and decorum; Competence and qualification; Confidentiality.

The document Good Judicial Practice: Principles and Issues established by the Swedish association of judges and courts of Sweden, different ethical issues have been addressed under different principles, which state what ought to be highlighted in a judge's actions and attitudes to ethical issues. Integrity is a key value. In this document, however, integrity is seen as a primary value that is reflected in four other principles: Independence, Impartiality and equal treatment, Good conduct and treatment of others, and Good expertise and efficiency.

A Guide to Judicial Conduct for England and Wales consists of nine chapters: Judicial Independence, Impartiality, Integrity, Propriety, Competence and Diligence, Personal Relationships and Perceived Bias, Activities outside the Court and after retirement. Differently from other European countries, this code sets the rules for judges after the retirement. It states that the conditions of appointment to the judicial office provide that judges accept appointment on the understanding that following the termination of their appointment they will not return to private practice as a barrister or a solicitor and will not provide services, on whatever basis, as an advocate in any court or tribunal in England and Wales or elsewhere. It is emphasized that even in retirement a former judge may still be regarded by the general public as a representative of the judiciary and any activity that might tarnish the reputation of the judiciary should be avoided.

Assessing the above-mentioned practice of European countries, it can be concluded that the main principles of judicial ethics in most of the European countries are fundamentally based on the Bangalore Principles of Judicial Conduct. There are differences in the constructions, comprehensiveness, content and legal instruments of implementation, but the codification of ethics is spreading in most of the countries. The Bangalore principles of Judicial Conduct are formulated in three 
parts: Value $\rightarrow$ Principle $\rightarrow$ Application. But the codes of judicial ethics in European countries additionally have validated the rules that judges shall observe to act in compliance with the principles of ethics. Therefore, the recommended structure of formalization of the code of judicial ethics could be established in this sequence: Values $\rightarrow$ Basic principles of conduct of judges $\rightarrow$ Rules that judges shall observe $\rightarrow$ Practical application. For example, the value "Professionalism" $\rightarrow$ the basic principles "Exemplarity" $\rightarrow$ the rule that judges shall observe "Show an example through conduct, language, discipline and presence according to the universally established moral norms" $\rightarrow$ practical application "Communication during a court session with the parties who disrespect the court and give false evidence".

Norms of judicial ethics have social benefit if they are properly implemented in practice and continuously developed by the judiciaries themselves. Therefore, the point here, having stated the basic principles and structure of code of judicial ethics, is to emphasize the importance of enforcement of judicial ethics.

\section{CHALLENGES IN ENFORCING JUDICIAL ETHICS}

In most European countries, judicial ethics is legally formalized and creates more or less significant legal consequences. Nevertheless, there is a lack of systematic provisions which would create a unified legal framework. As mentioned above, one reason for such a situation is the fact that the institution of judicial ethics is a relatively newer phenomenon than the long-lasting legal tradition. By general rule, for more coherent, comprehensive and effective regulation the supervision of legal norms should be established. The analysis of laws of European countries confirms that there is almost no regulation on the enforcement of judicial ethics in other European countries, and only some of them have direct provisions prescribed for it. The enforcement of rules of judicial conduct mostly lays on selfgovernance institutions, the officials of courts administration and, of course, on judges themselves. For example, the Law of the Republic of Lithuania on Courts establishes that the chairperson of the court shall supervise that activity of a judge would be in compliance with the requirements of the Code of judicial ethics (Article 103 part 4). Moreover, The Code of Ethics of the Judges of the Republic of Lithuania empowers the self-governance institutions and the officials of court administration to take necessary measures to ensure that the moral and ethical norms that are laid down in the code, Law on Courts, international legal acts would be known to every judge and every candidate to the position of a judge. However, in the countries that do not have regulatory provisions on enforcement the effectiveness of judicial ethics diminishes, even considering the fact that the ethical norms are 
more norms of inner culture and self-awareness of judges themselves and less likely imperatives of conduct.

During the practice of supervision of judicial ethics in Lithuanian courts, 43 many methods of enforcing the judicial ethics have been identified. First of all, judges themselves must acknowledge and realize the values of judicial ethics. There should be open discussion between judges about the values of judicial ethics: sharing experience and breaking absolutism. Judicial ethics should be on the everyday agenda and ethical dilemmas should be fearlessly raised between judges in everyday work. The ethical dilemmas must have a solution; therefore there should be decisions on ethical dilemmas and a setting of ethical standards jointly by principle of cooperation of judges. It is very important to have initial and continuous trainings on judicial ethics. From a practical point of view a constantly updated practical guide (guidelines) on code or other document of judicial ethics would provide clarity for other judges who happen to have the same dilemmas and would be a precondition for future developments. It is very important for a judge to have a possibility the official consultations made by special judicial self-government body or presidents of the courts, or special judges or groups on ethics (integrity).

It should be emphasized that for the judicial ethics is very important for the protection of the rights of judges and prevention of infringement of independence and impartiality. Therefore, the supervision of judicial ethics, on one hand, should be realistic and determinate (clear), but on the other hand, should be enforceable in respect of independence of judges. In a transitional country, the audio recordings of court sessions appeared to have a good preventive function in protecting subjects from breaking judicial ethics. Having highly principled and professionally prepared chairmen of the courts is a significant prerequisite for the proper internal administration of courts. Highly qualified internal administration of the courts is a key tool in ensuring control of judicial ethics. Special tools set in the court organizational action plan: analysis of judges' conduct in court hearings, control of long pending cases, internal meetings of judges, investigation of complaints. It is also very important that the investigations of violations of judicial ethics would have clear procedures, ensure judicial independence and human rights of judges, and have proportionate sanctions for breaking norms of judicial ethics.

It should also be emphasized that judiciary politics on judicial ethics is of high importance. First of all, there should be a broader and deeper approach to judicial ethics of a High Council of Justice that would lead to a long-term strategy. The system should recognize the separation of hard ethics and soft ethics and should

\footnotetext{
43 Author of the paper has served as a Chairman of Kaunas district court 2010-2015. From May of 2015 he continued service as a Chairman of the Civil cases division at Kaunas regional court. One of the functions of a Chairman is supervision of judicial ethics.
} 
certify clear performance standards. One of the hindrances in development is the wrongful general opinion that judicial ethics is for the inspection of judges which mostly leads to punishments of judges themselves. Therefore, a proper selection and protection mechanism should be established that judicial ethics would not be a tool to violate a judge's independence both from outside the court (parties, attorneys and state institutions) and from inside the court (wrongful inspections). In the commentary of Article 1 of Code of Judicial Ethics in Slovenia, it is correctly stated that "the enshrined principles would be abused if parties and their legal representatives were to refer to them in court proceedings in order to gain advantages in such proceedings". 44 Therefore, proper functioning of selfgovernment bodies, such as the Judicial Ethics and Discipline Commission for the investigation of the misconduct of judges, and special courts for hearing disciplinary cases of judges, are of high importance to protect the independence of judges and to make conditions for the developments of judicial ethics.

The high importance of judicial ethics in the administration of justice is undeniable; therefore, constant attention to the enforcement of judicial ethics should be paid not only by internal judiciaries of European countries, legal international organizations and bodies of judicial communities' cooperation, but by legal scholarship as well. High standards of judicial conduct, its sensitivity and diversity for administration of justice, which are determined by expectations of societies in European countries, require further research of professional activity of the judiciary, and, first of all, research of judicial ethics. This article is one of the first attempts to reveal a variety of establishments of judicial ethics and hopefully it will provoke discussions and further legal scientific studies.

\section{CONCLUSIONS}

1. Globalization processes and judicial cooperation between the judiciaries of different countries worldwide in the twenty-first century have led to the unification of the standards of judicial ethics. It is a global tendency of increasing significance of judicial ethics in the administration of justice. More and more countries grant increased significance and seek to reform and improve systems of judicial ethics. The Bangalore Principles of Judicial Conduct are the main source of modern judicial ethics in the world.

2. The complexity of judicial ethics is determined by judges' specific constitutional status, immunity and need for protection, as well as by wide scope of values, its sensitivity and diversity. It establishes a framework regulating judicial

${ }^{44}$ See The Code of Judicial Ethics of Slovenia, supra note 32. 
conduct and also encourages fundamental cultural values, which are essential for judiciary in the administration of justice.

3. The main objectives of judicial ethics are to enhance public confidence of the courts, to establish standards for ethical conduct of judges, to provide guidance to judges, to improve mutual human relations amongst judges, as well as to assist members of the executive and the legislature, lawyers and the public in general to better understand and support the judiciary.

4. The best practice of European countries is that the legal grounds to adopt the code of judicial ethics are established in laws. Nevertheless, norms of judicial ethics are based on the principle "judges to judges", because the nature of judicial ethics is a self-governing institution.

5. Most of the European countries have codified their judicial ethics by adopting special documents: codes, guidelines, declarations, booklets, principles, good judicial practice, etc.

6. The recommended structure for the formation of the code of judicial ethics is established in this sequence: Values $\rightarrow$ Basic principles of conduct of judges $\rightarrow$ Rules that judges shall observe $\rightarrow$ Practical application.

7. The collection of main principles of judicial ethics in European countries is identified in this list: independence; impartiality; integrity; justice; autonomy; constitutionality and legality; fairness; correctness; accountability; expertise; responsibility; prudence; discretion; propriety; equality; humanity; respect for human; the ability to listen to others; respect and loyalty for the state; respect for the public interest; wisdom; confidentiality; transparency; publicity; honesty; selflessness; incorruptibility; decency; decorum; exemplarity; courtesy; tolerance; dutifulness; solidarity; competence; diligence; courage; caution; open-mindedness; improvement of qualification; personal unselfishness; other generally recognized ethical standards.

8. The enforcement of judicial ethics requires systematic measures. First, it is very important that the judicial communities themselves would recognize the importance of judicial ethics in the administration of justice and would take appropriate actions in enforcing professional ethics. Judiciary politics on judicial ethics is of high importance, because it is a self-governing institution; therefore, there should be a broader and deeper approach to judicial ethics that would lead to a long-term strategy. 


\section{BIBLIOGRAPHY}

1. Cárdenas, Emilio J., and Héctor M. Chayer. "Corruption, accountability and the discipline of judges in Latin America." Global Corruption Report (2007): 44-48 $/ /$ http://unpan1.un.org/intradoc/groups/public/documents/undpadm/unpan045153.pdf.

2. Maitrepierre, Eric J. "Ethics, Deontology, Discipline of Judges and Prosecutors in France" // http://www.unafei.or.jp/english/pdf/RS_No80/No80_29VE_Maitrepierre.pdf.

3. Mayne, Greg. "Judicial integrity: the accountability gap and the Bangalore Principles." Global Corruption Report (2007): 40-44 // http://unpan1.un.org/intradoc/groups/public/documents/undpadm/unpan045153.pdf.

4. Schultz, Jessica. "The UNCAC and judicial corruption: Requirements and avenues for reform." Anti-Corruption Resource Centre (2009) // http://www.u4.no/publications/the-uncac-and-judicial-corruptionrequirements-and-avenues-for-reform/.

5. Terhechte, Jörg Philipp. "Judicial Ethics for a Global Judiciary - How Judicial Networks create their own codes of conduct." German Law Journal 10 (2009): $501-514 / /$

http://www.leuphana.de/fileadmin/user_upload/PERSONALPAGES/_st/terhech te_joerg-philipp/files/Judicial_Ethics_for_a_Global_Judiciary_-

_How_Judicial_Networks_Create_their_own_-_PDF_Vol_10_No_04_501514_SI_Articles_Terhechte.pdf.

6. The Cambridge Dictionary of Philosophy. $2^{\text {nd }}$ edition. Cambridge University Press 1995, 1999.

\section{LEGAL REFERENCES}

1. Bangalore Principles of Judicial Conduct (2002) // http://www.unodc.org/pdf/crime/corruption/judicial_group/Bangalore_principl es.pdf.

2. Bologna and Milan Global Code of Judicial Ethics (2015) // http://www.jiwp.org/\#!global-code-of-judicial-ethics/c1dnr.

3. Code of Ethics for Members of the Judiciary in Malta. The Commission for the administration of Justice (2004) // www.judiciarymalta.gov.mt/code-of-ethics. 
4. Code of Ethics of Judges of the Republic of Lithuania. The General meeting of the Lithuanian judges (2006) //

http://www.judicial-

ethics.umontreal.ca/en/codes\%20enonces\%20deonto/documents/Code_lituan ie.pdf.

5. Code of Judicial Ethics of International Criminal Court. ICC-BD/02-01-05 //

https://www.icc-cpi.int/NR/rdonlyres/A62EBC0F-D534-438F-A128-

D3AC4CFDD644/140141/ICCBD020105_En.pdf.

6. Code of Judicial Ethics of the Republic of Croatia. The Council of presidents of all councils of Judges of the Republic of Croatia (2006) // http://pak.hr/cke/propisi,\%20zakoni/en/CodeofJudicalEthics/EN.pdf.

7. Code of Judicial Ethics. Adopted in 1995 by the Conference of Judges of the Republic of Latvia // http://webcache.googleusercontent.com/search?q=cache:TquFvYQa1V0J:at.g ov.Iv/files/uploads/files/archive/department1/tiesnesu_etikas_kodekss_eng.d $\mathrm{oc}+\& \mathrm{~cd}=1 \& \mathrm{hl}=|\mathrm{t} \& \mathrm{ct}=\mathrm{clnk} \& \mathrm{gl}=| \mathrm{t}$.

8. Commentary on the Bangalore Principles of Judicial Conduct (September 2007) //

https://www.unodc.org/documents/corruption/publications_unodc_commenta ry-e.pdf.

9. Delcourt v. Belgium. European Court of Human Rights (ECHR), January 17, $1970 / /$

http://hudoc.echr.coe.int/eng\#\{"appno":["2689/65"],"itemid":["00157467"]\}.

10. Deontological Code for Judges and Prosecutors. Superior Council of Magistracy of Romania (2005) // www.csm1909.ro/csm/linkuri/15_11_2005_2048_en.doc.

11. Estonian Judges' Code of Ethics. The Court en banc (2004) // http://www.nc.ee/?id=682.

12. Ethical Principles for Judges. The Association of Danish Judges (2014) // http://dommerforeningen.dk/english/ethical-principles-for-judges/.

13. Ethical Principles for Norwegian Judges. The Norwegian Association of Judges (2010) //

http://www.coe.int/t/dghl/cooperation/CCJE/cooperation/Ethical\%20_principl es_Norwegian_judges.pdf.

14. Good Judicial Practice. Principles and Issues. Swedish association of judges and Courts of Sweden (2013) // 
http://www.domstol.se/Publikationer/Rapporter/god_domarsedgrundsatser_och_fragor_eng.pdf.

15. Guide for Magistrates, Principles, Values and Qualities. Published in 2012 by the Belgian High Council of Justice // http://www.csj.be/sites/default/files/press_publications/o0023f.pdf.

16. Guide to Judicial Conduct. The Judges' Council of England and Wales (2013) // https://www.judiciary.gov.uk/wpcontent/uploads/JCO/Documents/Guidance/judicial_conduct_2013.pdf.

17. Judges Ethics Code. Adopted in 2012 by Association of Georgian Judges // http://www.supremecourt.ge/eng/judges-self-governance/judges-ethicscode/.

18. Judicial Ethics Report 2009-2010. ENCJ Working Group // http://www.encj.eu/images/stories/pdf/ethics/judicialethicsdeontologiefinal.p df.

19. NVVR Guide to Judicial Conduct of the Dutch Judges Association: 87-125. In: Matters of Principle. Codes on the Independence and Impartiality of the Judiciary. The Dutch Foundation 'Judges for Judges' // https://www.rechtspraak.nl/SiteCollectionDocuments/Matters-of-principle.pdf.

20. Opinion no. 3 of the Consultative Council of European Judges (CCJE) to the attention of the Committee of Ministers of the Council of Europe on the principles and rules governing judges' professional conduct, in particular ethics, incompatible behaviour and impartiality. Strasbourg (November 19, 2002) //

https://wcd.coe.int/ViewDoc.jsp?p=\&id=1046405\&Site=COE\&direct=true.

21. Organic Law of Georgia on Common Courts // https://matsne.gov.ge/en/document/download/90676/13/en/pdf.

22. Resolution on Judicial ethics adopted by the European Court of Human Rights (Plenary Court) (June 23, 2008) //

http://www.echr.coe.int/Documents/Resolution_Judicial_Ethics_ENG.pdf.

23. The Code of Conduct for Judicial Personnel: 81-85. In: Matters of Principle. Codes on the Independence and Impartiality of the Judiciary. The Dutch Foundation 'Judges for Judges' //

https://www.rechtspraak.nl/SiteCollectionDocuments/Matters-of-principle.pdf.

24. The Code of Judicial Ethics in Italy. Adopted in 1994 by the National Association of Judges //

http://www.judicialethics.umontreal.ca/en/codes\%20enonces\%20deonto/documents/CODE_ITAL IEN.pdf. 
25. The Code of Judicial Ethics of Slovenia. The Association of Judges of the Republic of Slovenia (2001) //

http://www.judicial-

ethics.umontreal.ca/en/codes\%20enonces\%20deonto/documents/SLOVENIACODEOFJUDICIALETHICS.pdf.

26. The Ethical Code of Judicial Conduct. The Judicial Council of the Slovak Republic (2010) //

http://www.sudcovia.sk/sk/dokumenty/legislativa/39-englishcategories/documents/archive/401-theet-codeofju-cond.

27. The Statement of Principles of Judicial ethics for the Scottish Judiciary (2010) // http://www.scotlandjudiciary.org.uk/Upload/Documents/StatementofPriciplesofJudicialEthicsforthe ScottishJudiciary.pdf. 